\title{
Chromosomal Differentiation between Populations of Oligosarcus hepsetus (Teleostei, Characidae) from Small Tributaries at Opposite Margins of the Paraíba do Sul River (Brazil)
}

\author{
Liano Centofante ${ }^{1}$, Luiz Antonio Carlos Bertollo ${ }^{2}$ and Orlando Moreira-Filho ${ }^{2^{*}}$ \\ ${ }^{I}$ Departamento de Biologia e Zoologia; Instituto de Biociências; Universidade Federal do Mato Grosso; Av. Fernando \\ Corrêa, s/n; Coxipó; 78060-900; Cuiabá - MT - Brasil. ${ }^{2}$ Departamento de Genética; Universidade Federal de São \\ Carlos; Via Washington Luis, Km 235; C. P. 676; omfilho@power.ufscar.br; 15565-905; São Carlos - SP - Brasil
}

\begin{abstract}
Cytogenetic analyses were carried out in two populations of Oligosarcus hepsetus from tributaries at opposite margins of the Paraíba do Sul river. The same diploid number was observed in both populations $(2 n=50)$, but they showed remarkable differences related to karyotype formula and distribution of rDNA sites as revealed by silver nitrate staining and in situ hybridization with $18 S$ probes. The results suggested that the main channel of the Paraíba do Sul river acted as barrier to gene flow between populations.
\end{abstract}

Key words: Fish, headstream, cytogenetic, differentiation

\section{INTRODUCTION}

Oligosarcus hepsetus is a fish species distributed along Brazilian coastal rivers from Rio de Janeiro (Southeastern region) to Santa Catarina (Southern region) (Menezes, 1987). It represents one of the 16 species of the widespread Oligosarcus genus (Menezes, 1987), whose phylogenetic position in the family Characidae remains controversial (Lima et al., 2003). Cytogenetic analyses were previously carried out in $O$. hepsetus (Falcão and Bertollo, 1985; Hattori et al., 2002; Kavalco, 2003), $O$. jenynsii (Falcão and Bertollo, 1985; Veiga et al., 1998; Hattori et al., 2002), O. longirostris (Cestari, 1996; Cunha et al., 2001; Rubert and Margarido, 2004), O. macrolepis (Falcão and Bertollo, 1985), $O$.paranaensis (Mortati and Dias, 2002), $O$. paranensis (Martinez and Julio Jr., 2001; Rubert and Margarido, 2004) and O. pintoi (Falcão and Bertollo 1985; Hattori et al., 2002; Rubert and Margarido, 2004). All these species have the same diploid number $(2 \mathrm{n}=50)$ and an asymmetric karyotype, but they can be differentiated by karyotypic formulae and/or Ag-NOR patterns.

The present study describes a chromosomal differentiation in two $O$. hepsetus populations from tributaries at opposite margins of the Paraíba do Sul river.

\section{MATERIAL AND METHODS}

Cytogenetic analyses were carried out in 540 metaphases of Oligosarcus hepsetus (10 females

\footnotetext{
* Author for correspondence
} 
and 8 males) from Grande stream, a tributary on the left margin of the middle Paraíba do Sul river $\left(22^{\circ} 46^{\prime} 2.98^{\prime \prime} \mathrm{S}\right.$ and $\left.45^{\circ} 26^{\prime} 7.05^{\prime \prime} \mathrm{W}\right)$, and in 590 metaphases of Oligosarcus hepsetus (11 females and 9 males) from Santo Antônio stream, a tributary on the right margin of the middle Paraíba do Sul river $\left(22^{\circ} 35^{\prime} 14.8^{\prime \prime} \mathrm{S}\right.$ and $\left.44^{\circ} 42^{\prime} 46.2^{\prime \prime} \mathrm{W}\right)$. The chromosomal preparations were obtained according to Bertollo et al., (1978). Constitutive heterochromatin and nucleolar organizer regions (Ag-NORs) were detected according to Sumner (1972) and Howell and Black (1980), respectively. Sequential bandings followed the procedure suggested by Centofante et al. (2002). The chromosomal location of the $18 \mathrm{~S}$ sites was obtained by fluorescent in situ hybridization, (FISH) as reported by Pinkel et al. (1986), using a $18 \mathrm{~S}$ rDNA probe isolated from Prochilodus argenteus (Hatanaka and Galetti Jr., 2004) The chromosomal morphology was based on arm ratio (Levan et al., 1964).

\section{RESULTS}

The population of $O$. hepsetus from Ribeirão Grande stream presented a diploid number of $2 n=50$ chromosomes, with a karyotype formula composed by 6 metacentric chromosomes (M), 12 submetacentric chromosomes (SM), 14 subtelocentric chromosomes (ST) and 18 acrocentric chromosomes (A) (Fig. 1a). No heteromorphism related to sex was observed.

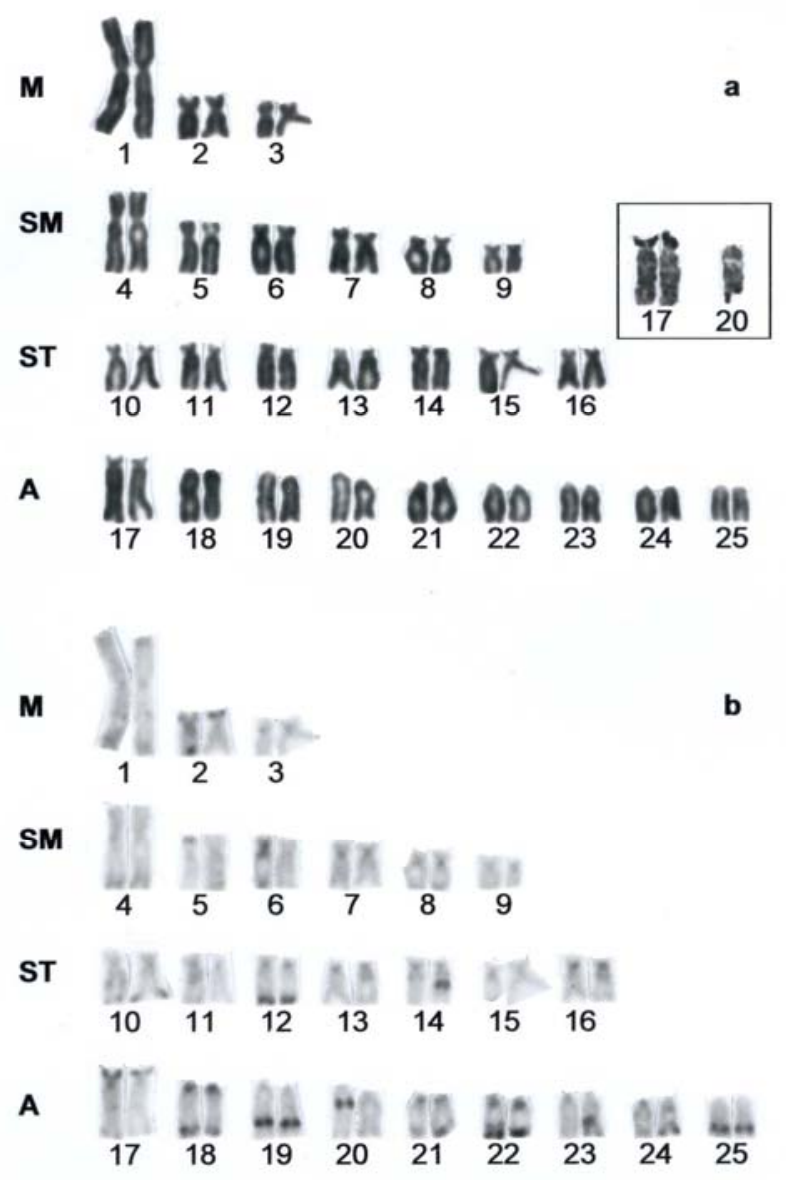

Figure 1 - Karyotypes of Oligosarcus hepsetus from the Ribeirão Grande stream. (a) Giemsa stained and (b) C-banded. In the box the chromosomes bearing Ag-NORs. Bar= $5 \mu \mathrm{m}$. 


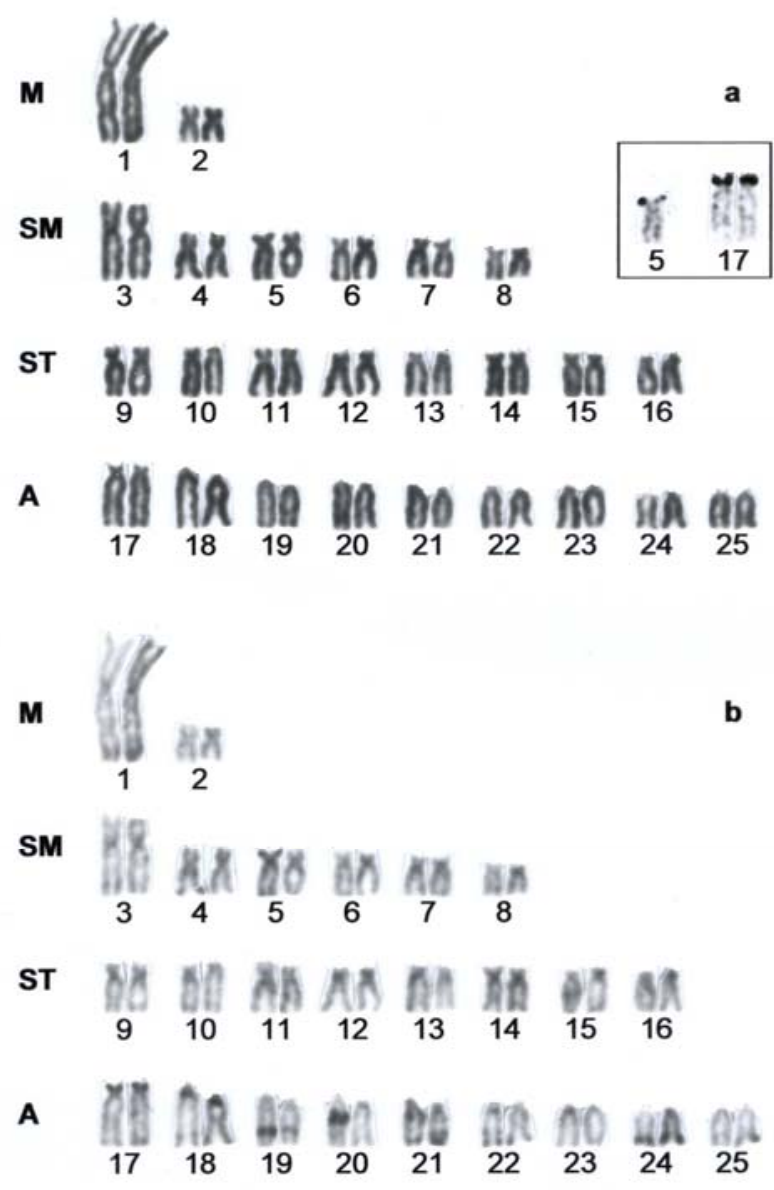

Figure 2 - Karyotypes of Oligosarcus hepsetus from the Santo Antônio stream. (a) Giemsa stained and (b) C-banded. In the box the chromosomes bearing Ag-NORs. Bar $=5 \mu \mathrm{m}$.

Ag-NORs were observed in three chromosomes; one homologous from the $20^{\text {th }}$ acrocentric pair at the telomeric region on the long arm, and both chromosomes from the $17^{\text {th }}$ acrocentric pair at the telomeric region on the short arms (Fig. 1 box). FISH with $18 \mathrm{~S}$ rDNA probe showed an additional site to those identified by silver nitrate staining (Ag-NORs) totalizing four positive signals (Fig. 3a). The constitutive heterochromatin (C-bands) was observed at pericentromeric region of the entire chromosomal set, besides some conspicuous segments at telomeric region on both arms of the pairs 1,18 and 22; at telomeric region on the short arms of the pairs 2, 17, and in one homologous from the pair 5; at telomeric region on the long arms of the pairs 4, 10, 12, 21 and 24; at interstitial region on the long arms of one homologous from the pairs 14 and 20; and at subterminal region on the long arms of the pairs 19 and 25 (Figs. 1b and 4a).

The population of $O$. hepsetus from Santo Antônio stream presented a diploid number of $2 n=50$ chromosomes, divided into 4M, 12SM, 16ST and 18A (Fig. 2a). Ag-NORs were observed at the telomeric region on the short arms of three chromosomes, one homologous from the pair 5 (submetacentric) and both chromosomes from the pair 17 (acrocentric) (Fig. 2 box). By using in situ hybridization with $18 \mathrm{~S}$ rDNA probe, three additional NOR sites were identified, besides those previously observed by silver nitrate staining, comprising six positive signals (Fig. 3b). 

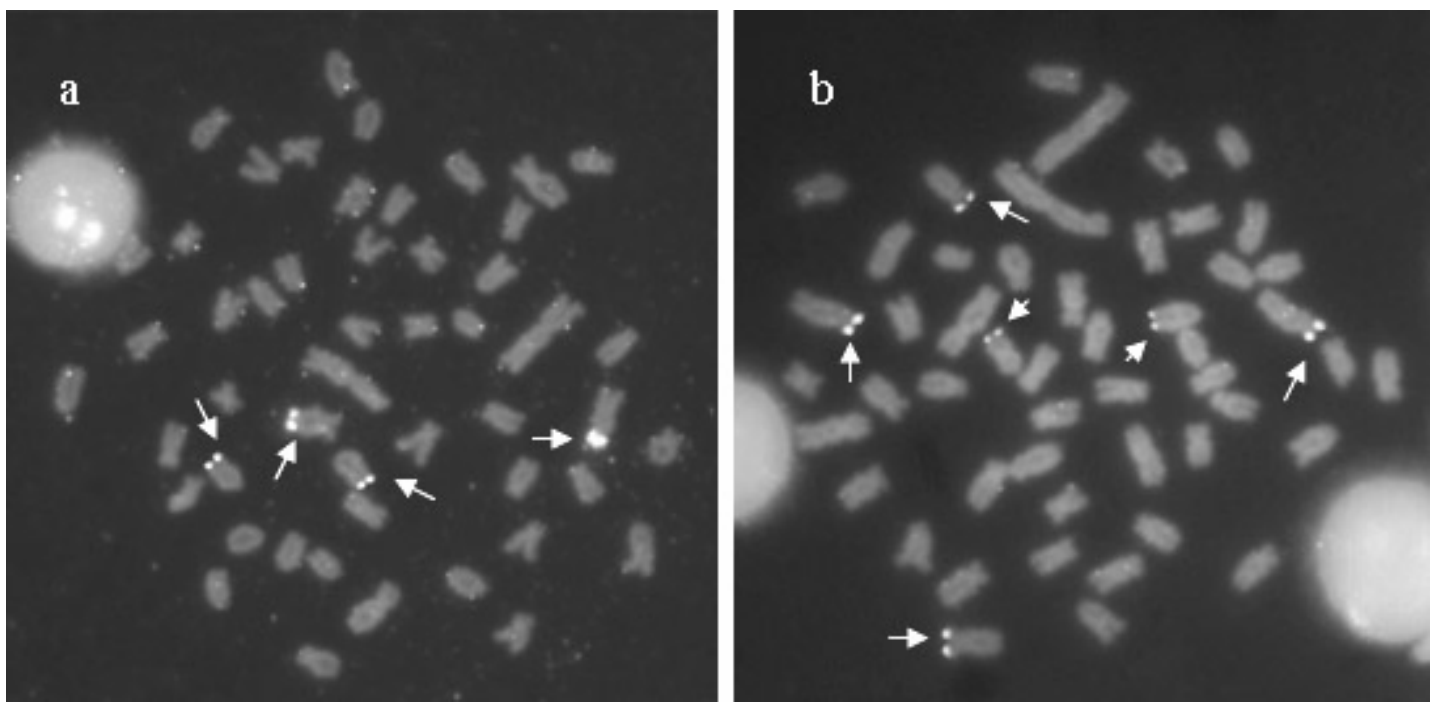

Figure 3 - "In situ" hybridization with 18S rDNA probe in Oligosarcus hepsetus. (a) population from Ribeirão Grande stream and (b) population from Santo Antônio stream.

C-bands were distributed on the pericentromeric region of all chromosomes, some conspicuous blocks were observed at telomeric region on both arms of the pairs 21 ; at telomeric region on the long arms of the pairs 1 and 24; at interstitial region of one homologous from the pair 20; and at subterminal region of the pair 19 (Figs. $2 b$ and $4 b$ ).

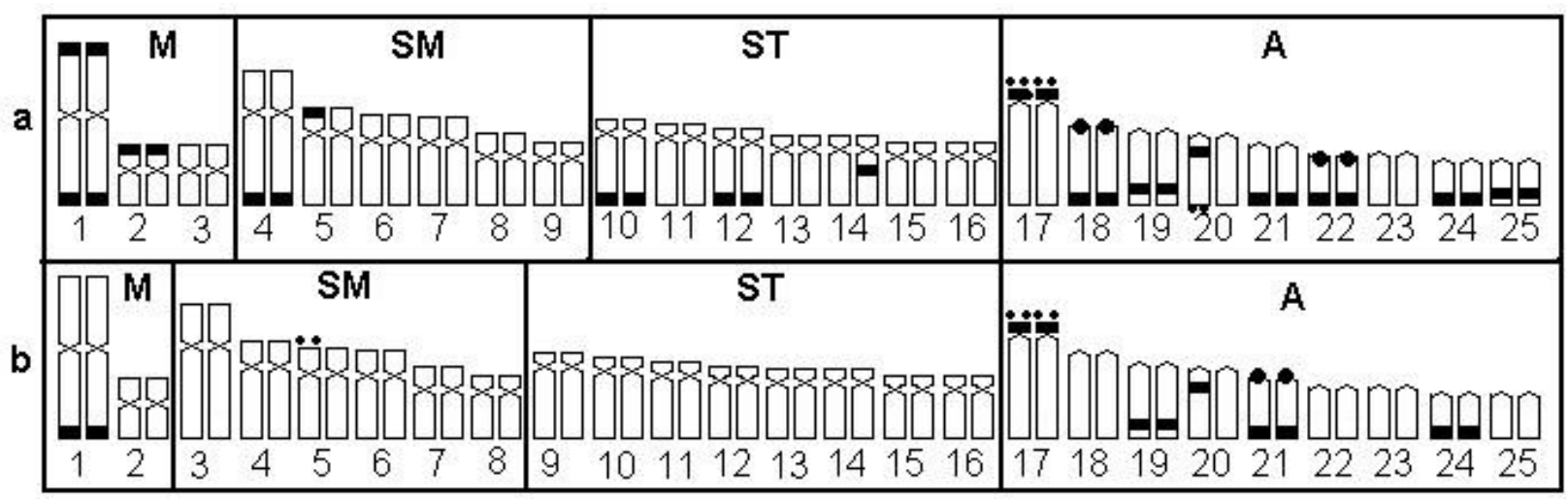

Figure 4 - Karyogram showing C-bands and Ag-NORs. (a) population from Ribeirão Grande stream and (b) population from Santo Antônio stream.

\section{DISCUSSION}

The relevance of studies focusing headwater environment has been stressed by LoweMcConnel (1969), stating that large tropical river systems allowed some species from tributary headwaters to become geographically isolated from each other by physical, chemical or biotic barriers.
Both populations of $O$. hepsetus herein analyzed presented the same diploid number $(2 \mathrm{n}=50)$, but they could be differentiated by the karyotype formulae: $6 \mathrm{M}+12 \mathrm{SM}+14 \mathrm{ST}+18 \mathrm{~A}$ for the population from Ribeirão Grande stream and $4 \mathrm{M}+12 \mathrm{SM}+16 \mathrm{ST}+18 \mathrm{~A}$ for the population from Santo Antônio stream. These chromosomal differentiations were probably due to nonRobertsonian rearrangements concerning the metacentric and subtelocentric chromosomes. 
With regards to Ag-NORs, both populations shared the location of one site at the telomeric region on the short arm of the pair 17. However, exclusive Ag-NOR sites to each population could be observed, at one homologue from the pair 20 (acrocentric) in the Ribeirão Grande population and at one homologue from the pair 5 (submetacentric) in the Santo Antônio population. After in situ hybridization with 18S rDNA probe, it was possible to observe four signals in the population from Ribeirão Grande stream (corresponding to pairs 17 and 20) and six signals in the population from Santo Antônio river (corresponding to pairs 5, 17, and probably to 24). Such differences in the number of ribosomal sites between populations can be ascribed to transpositions, often referred as the putative chromosomal rearrangement responsible for the dispersion of nucleolar organizer regions in fish (Galetti Jr. et al., 1995; Almeida-Toledo et al., 1996; Mantovani et al., 2000).

After C-banding, it was also possible to observe diagnostic bands to each population, spread out over telomeric, subtelomeric and interstitial chromosomal regions (Fig. 4), besides a heterozigous polymorphism in some chromosome pairs. Such C-band polymorphism was previously observed in other fish species (Mantovani et al., 2000; Vicari et al., 2003) coupled with the occurrence of homozygotes specimens for the presence and absence of C-bands. Differently, homozygotes were not detected in the populations of $O$. hepsetus. These results could be related to the sample size analyzed or could represent a recent chromosomal event. According to John (1980), the occurrence of chromosomal rearrangements is not widespread, being rare their simultaneous incidence in homologous chromosomes. Therefore, in natural populations, structural rearrangements are introduced in a heterozygous condition and homozygotes offsprings are established by random matings.

Populations of $O$. hepsetus from Paraitinga river and Jacuí stream, tributaries from the upper Paraíba do Sul river, showed similar chromosomal features: $2 \mathrm{n}=50$ chromosomes and a karyotype composed by $6 \mathrm{M}+10 \mathrm{SM}+16 \mathrm{ST}+18 \mathrm{~A}$, with a single chromosome pair (17) bearing Ag-NORs, and two chromosome pairs (17 and 23) bearing 18S rDNA sites (Kavalco, 2003). However, when these populations were compared to that from the present study, significant differences related to number of biarmed chromosomes and location of rDNA sites were seen.

The present populations of $O$. hepsetus, as well as those previously analyzed (Kavalco 2003), shared the location of Ag-NORs on 17th pair, indicating the it was a major NOR site. This has been also observed in other fish populations, as in Astyanax scabripinnis (Mizoguchi and Martins-Santos, 1998a). Similarly, the number of acrocentric chromosomes also remained constant among $O$. hepsetus populations, while the number of biarmed chromosomes was variable due to nonRobertsonian rearrangements. An opposite situation was observed among A. scabripinnis populations, where the number of metacentric chromosomes was conserved and the number of acrocentric chromosomes were variable, leading to alterations in the diploid number. In this case, both Robertsonian and non-Robertsonian rearrangements were invoked to explain these differences (Moreira-Filho and Bertollo 1991). Apparently depending on the fish group, some chromosomes were not able to change their structural organization and, therefore, they remained constant among populations, as in the case of acrocentric chromosomes in $O$. hepsetus and metacentric chromosomes in A. scabripinnis.

Chromosomal differences between populations from a same hydrographic basin were also observed in Trichomycterus paolence (Torres et al., 1998), A. scabripinnis (Moreira-Filho and Bertollo, 1991; Mizoguchi and Martins-Santos, 1998b; Alves and Martins-Santos, 2002; Fernandes and Martins-Santos, 2003). Such populational variability seemed to be a recurrent event in distinct taxa that lived in small populations restricted to streams. Moreira-Filho and Bertollo (1991) has described the importance of these habitats for the fixation of chromosomal rearrangements in A. scabripinnis.

Studies carried out by Caramaschi (1986) about the ichthyofauna from Tietê and Paranapanema rivers (Paraná river basin) demonstrated that Oligosarcus pintoi and $O$. paranensis were distributed along streams of third order, avoiding the main river channel. Most likely, the populations of $O$. hepsetus might present the same distribution pattern, limited to its respective streams, and the main channel of Paraíba do Sul river would act as a barrier to gene flow between populations. If so, the formation of small isolates would favour the fixation of chromosomal 
rearrangements leading to genetic differentiation between populations.

\section{ACKNOWLEDGEMENTS}

This study was supported by FAPESP (Fundação de Amparo à Pesquisa do Estado de São Paulo) and $\mathrm{CNPq}$ (Conselho Nacional de Desenvolvimento Científico e Tecnológico).

\section{RESUMO}

Análises citogenéticas foram realizadas em duas populações de Oligosarcus hepsetus provenientes de riachos de margens opostas do rio Paraíba do Sul. O número diplóide foi o mesmo para ambas as populações $(2 \mathrm{n}=50)$, porém diferenças significativas foram observadas com relação à fórmula cariotípica e distribuição dos sítios de DNAr detectados pela impregnação por prata e pela hibridação "in situ" com sonda $18 \mathrm{~S}$. Estes resultados sugerem que a calha principal do rio Paraíba do Sul estaria atuando como uma barreira para o fluxo gênico entre essas populações.

\section{REFERENCES}

Almeida-Toledo, L. F.; Bigoni, A. P.; Bernardino, G.; Foresti, F. and Toledo-Filho, S. A. (1996), Karyotype and NOR conservatism with heterochromatin reorganization in Neotropical Bryconids. Caryologia, 49, 35-43.

Alves, A. L. and Martins-Santos, I. C. (2002), Cytogenetics studies in two populations of Astyanax scabripinnis with $2 \mathrm{n}=48$ chromosomes (Teleostei, Characidae). Cytologia, 67, 117-122.

Bertollo, L. A. C.; Takahashi, C. S. and Moreira-Filho, O. (1978), Cytotaxonomic considerations on Hoplias lacerdae (Pisces, Erythrinidae). Brazilian Journal of Genetics, 1, 103-120.

Caramaschi, E. P. (1986), Distribuição da ictiofauna de riachos das bacias do Tietê e do Paranapanema, junto ao divisor de águas (Botucatu, SP). Tese (Doutorado) - Universidade Federal de São Carlos, São Carlos. 245 pp.

Centofante, L.; Porto, J. I. R. and Feldberg, E. (2002), Chromosomal polymorphism in Serrasalmus spilopleura Kner, 1858 (Pisces, Serrasalminae) from central amazon. Caryologia, 55, 37-45.
Cestari, M. M. (1996), Estudos citogenéticos preliminares de peixes pertencentes a bacia do rio Iguaçu. In: Encontro Paranaense de Genética, 3.,Curitiba. Resumo ... Curitiba. Item 3.1.1.9.

Cunha, E. B.; Pegoraro, J. L. and Margarido, V. P. (2001), Análise citogenética comparativa de duas espécies de Oligosarcus (Pisces, Characidae, Acestrorhynchinae). In: Congresso Nacional de Genética, 47., Águas de Lindóia. Resumo ... Águas de Lindóia. CD-ROM.

Falcão, J. N. and Bertollo, L. A. C. (1985), Chromosome characterization in Acestrorhynchinae and Cynopotaminae (Pisces, Characidae). Journal Fish Biology, 27, 603-610.

Fernandes, C. A. and Martins-Santos, I. C. (2003), Cytogenetic characterization of two populations of Astyanax scabripinnis (Pisces, Characiformes) of the Ivaí basin, PR, Brazil. Cytologia, 68 : (3), 289-293.

Galetti Jr., P. M.; Mestriner, C. A.; Monaco, P. J. and Rasch, E. J. (1995), Post-zigotic modifications and intra- and interindividual nucleolar organizing region variations in fish: report of a case involving Leporinus friderici. Chromosome Research, 3, 285-290.

Hatanaka, T. and Galetti Jr., P. M. (2004), Mapping of the $18 \mathrm{~S}$ and $5 \mathrm{~S}$ ribosomal genes in the fish Prochilodus argenteus Agassiz, 1829 (Characiformes, Prochilodontidae). Genetica, 122, 239-244.

Hattori, R. S.; Lopes, C. E. and Almeida-Toledo, L. F. (2002), Estudos citogenéticos comparativos em três espécies do gênero Oligosarcus (Pisces, Characiformes). In: Congresso Nacional de Genética, 48., Águas de Lindóia. Resumo ... Águas de Lindóia. CD-ROM.

Howell W. M. and Black D. A. (1980), Controlled silver-staining of nucleolus organizer regions with a protective colloidal developer: a 1-step method. Experientia, 36, 1014-1015.

John, B. (1980), Citogenética de Populações. São Paulo: EDUSP.

Kavalco, K. F. (2003), Contribuição genética à análise da biodiversidade da ictiofauna das nascentes do rio Paraitinga. Dissertação (Mestrado) - Universidade Federal de São Carlos, São Carlos-SP, 141 pp.

Levan A.; Fredga K. and Sandberg A. A. (1964), Nomenclature for centromeric position on chromosomes. Hereditas, 52, 201-220.

Lima, F. C. T; Malabarba, L. R.; Buckup, P. A.; Silva, J. F. P.; Vari, R. P.; Harold, A.; Benine, R.; Oyakawa, O. T.; Pavanelli, C. S.; Menezes, N. A.; Lucena, C. A. S.; Malabarba, M. C. S. L.; Lucena, Z. M. S.; Reis, R. E.; Langeani, F.; Cassati, L.; Bertaco, V. A.; Moreira, C. and Lucinda, P. H. F. (2003), Genera incertae sedis in Characidae. In: Reis, R. E.; Kullander, S. O. and Ferraris Jr., C. J. (EDs.). Check list of the freshwater fishes of South and Central America. Porto Alegre: EDIPUCRS. 742 pp. 
Lowe-MacConnell, R. A. (1969), Speciation in tropical freshwater fishes. Biology Journal Linnean Society, 1, 51-75.

Mantovani, M.; Abel, L. D. S.; Mestriner, C. A. and Moreira-Filho, O. (2000), Accentuated polymorphism of heterochromatin and nucleolar organizer regions in Astyanax scabripinnis (Pisces, Characidae): tools for understanding karyotypic evolution. Genetica, 109, 161-168.

Martinez, E. R. M. and Julio Jr., H. F. (2001), Análise citogenética de Oligosarcus cf. paranensis (Characidae, Acestrorhynchinae) do ribeirão Keller, bacia do Paraná. In: Congresso Nacional de Genética, 47., Águas de Lindóia. Resumo ... Águas de Lindóia. CD-ROM.

Menezes, N. A. (1987), Três espécies novas de Oligosarcus Gunther, 1864 e redefinição taxonômica das demais espécies do gênero (Osteichthyes, Teleostei, Characidae). Boletim de Zoologia da Universidade de São Paulo, 11, 1-39.

Mizoguchi, S. M. H. N. and Martins-Santos, I. C. (1998a), Activation patterns of the nucleolar organizer regions in Astyanax scabripinnis populations (Pisces, Characidae). Cytologia, 63 : (3), 259-265.

Mizoguchi, S. M. H. N. and Martins-Santos, I. C. (1998b), Cytogenetic and morphometric differences in populations of Astyanax scabripinnis (Pisces, Characidae) from Maringá region, PR, Brazil. Genetics and Molecular Biology, 21 : (1), 55-61

Moreira-Filho, O. and Bertollo, L. A. C. (1991), Astyanax scabripinnis (Pisces, Characidae): a species complex. Brazilian Journal of Genetics, 14, 331-357.

Mortati, A. F. and Dias, A. L. (2002), Análise do padrão de distribuição da heterocromatina constitutiva em duas populações de Oligossarcus paranensis (Pisces, Characidae), da bacia do rio Tibagi-PR. In: Simpósio de Citogenética e Genética de Peixes, 9., Natal. Resumo ... Natal. pp. 34.

Pinkel, A. M.; Straume, T. and Gray, J. W. (1986), Cytogenetics analysis using quantitative, highsensitivy, fluorescence hybridization. Proceedings of the National Academy of Sciences, 83, 2934-2938.
Rubert, M. and Margarido, V. P. (2004), Análise citogenética em três espécies do gênero Oligosarcus (Characiformes, Characidae, Acestrorhynchinae). In: Simpósio de Citogenética e Genética de Peixes, 10., Natal. Resumo ... Natal. pp. 70.

Sumner, A. T. (1972), A simple technique for demonstrating centromeric heterochromatin. Experimental Cell Research, 75, 304-306.

Veiga, L. C. S.; Vieira, M. M. R. and Foresti, F. (1998), Estudos citogenéticos em Oligosarcus jenynsii (Pisces, Characidae). In: Congresso Nacional de Genética, 44., Águas de Lindóia. Resumo ... Águas de Lindóia. pp. 64.

Vicari, M. R.; Artoni, R. F. and Bertollo, L. A. C. (2003), Heterochromatin polimorphism associated with 18S rDNA: a differential pathway among Hoplias malabaricus fish populations. Cytogenetic and Genome Research, 101, 24-28.

Torres, R. A.; Foresti, F. and Oliveira, C. (1998), Comparative cytogenetic studies in alopatric populations of Tricomycterus paolence (Siluriformes, Tricomycteridae). Cytologia, 63, 107-114.

Received: March 08, 2005; Revised: September 16, 2005 ; Accepted: July 17, 2006. 